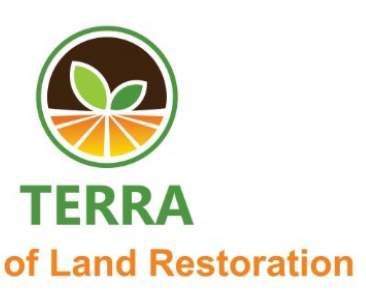

\title{
Growth and Yield Component of Two Varieties of Soybeans (Glycine max L. Merril) in Some Types of Amelioration in Ultisol
}

\author{
Siska Indriani ${ }^{1}$, Dotti Suryati ${ }^{1}$, Hesti Pujiwati ${ }^{1 *}$, Prasetyo ${ }^{1}$, Entang Inoriah Sukarjo ${ }^{1}$ \\ ${ }^{1}$ Agroecotechnology Department, University of Bengkulu, Bengkulu, 38121, Indonesia \\ email: hesti_pujiwati@unib.ac.id
}

\begin{abstract}
Soybeans are the third most important commodity after rice and corn. Soybeans are also a commodity rich in protein. Soy serves as a very important source of vegetable protein to improve people's nutrition because in addition to being safe for health is also relatively cheap compared to animal protein sources. Ultisol has a wide distribution but has constraints to be used as a medium of cultivation plants. The addition of some types of ameliorating or soil reformers such as chicken manure, cow manure, and composting oil palm bunches (OPB) is expected to overcome ultisol fertility. The purpose of this study was to compare the influence of varieties on the growth and component of soybean crop yields in Ultisol, compare the influence of ameliorating type on the growth and component of soybean crop yields in Ultisol, and get the interaction between the type of varieties with the type of amelioration to the growth and components of soybean crop yields in Ultisol. The research was conducted from February to May 2019 in the experimental garden of Integrated Agricultural Zone of the Faculty of Agriculture UNIB Medan Baru, Bengkulu City. This study used a Complete Randomized Design (CRD) that was compiled factorially with 3 times. The first factor is the variety type Anjasmoro and Gepak Kuning, the second factor of amelioration type is control (without amelioration), chicken manure 15 tons ha $\mathrm{h}^{-1}$, cow manure 15 tons ha $\mathrm{h}^{-1}$, husks burn 15 tons ha $\mathrm{h}^{-1}$, and compost oil palm bunches (OPB) 15 tons $h^{-1}$. The results showed that the Gepak Kuning variety showed better growth than the Anjasmoro variety while the Anjasmoro variety showed better results than the Gepak Kuning variety. Chicken manure is the best type of amelioration compared to cow manure, rice husks, and compost OPB against the growth and component of soybean yields in Ultisol, and there is interaction in the Gepak Kuning variety with chicken manure amelioration and compost $O P B$.
\end{abstract}

Keywords : soybean, Ultisol, amelioration

\section{INTRODUCTION}

Soybeans (Glycine max (L.) Merrill) is the third most important commodity after rice and corn. Soybeans are also a commodity-rich in protein. Soy serves as a very important source of vegetable protein to improve people's nutrition because in addition to being safe for health is also relatively cheap compared to animal protein sources (Sudaryanto \& Swastika, 2007). According to Tanuwijaya et al. (2016) in $100 \mathrm{~g}$ of soybeans contains the energy of $381 \mathrm{kcal}$, protein $40 \mathrm{~g}$, fat $12.7 \mathrm{~g}$, and carbohydrates $249 \mathrm{~g}$.

National soybean production fluctuated in the last four years from 2015 to 2018 , namely 963,183 tons, 859,653 tons, 538,728 tons, and 982,598 tons. (Kementerian Pertanian RI, 2018). Such production has not been able to meet the consumption of soybeans in the country. This is evidenced by soybean imports from 2015 to 2017 amounting to 2,292,947 tons, 2,042,947 tons, and 2,292,415 tons (Badan Pusat Statistik, 2017). Soybean production in Bengkulu also fluctuated in the last four years from 2015 to 2018, namely 5,388 tons, 4,664 tons, 413 tons, and 3,477 tons (Kementerian Pertanian RI, 2018). One of the factors causing soybean production in Bengkulu Province to fluctuate is the condition of the soil that lacks nutrients, especially in Ultisol. According to Prasetyo \& Suriadikarta (2006), about 25\% of the total land area in Indonesia whose distribution reaches $45,794,000$ ha is Ultisol. The most widespread distribution in Indonesia is in Kalimantan which is $21,938,000$ ha further in Sumatra of 9,469,000 ha followed by Maluku, and Papua at 8,859,000 ha, Sulawesi 4,303,000 ha, Java 1,172,000 ha, and Nusa Tenggara 53,000 ha.

Ultisol is a type of sour soil that has low organic matter and macronutrients, especially $\mathrm{K}, \mathrm{Ca}$, and $\mathrm{Mg}$, and has a very low $\mathrm{P}$ availability and high $\mathrm{Al}$ saturation. 
To overcome this can be applied calcification technology, fertilization $\mathrm{N}, \mathrm{P}, \mathrm{K}$, and the provision of organic matter (Fitriatin et al., 2014). According to Syahputra et al. (2015) ultisol is characterized by the texture of clay, sandy clay, and sandy clay with red yellow soil, and soil $\mathrm{pH}$ of about 4.3 to 4.9 with Al-dd values ranging from $0.55 \mathrm{me} 100 \mathrm{~g}^{-1}$ to $4.72 \mathrm{me}^{100 \mathrm{~g}^{-1} \text { and }}$ aluminum saturation values ranging from $4.72 \mathrm{me}^{100 \mathrm{~g}^{-1}}$ 10.74 to $75.64 \%$ with C-organic values $0.13 \%$ to $1.12 \%$, $\mathrm{P}$ total ranging from $0.048 \%$ to $0.053 \%$, N-total $0.09 \%$ to $0.18 \%$, P-available soil $0.53 \mathrm{ppm}$ to $2.00 \mathrm{ppm}$, soil CEC

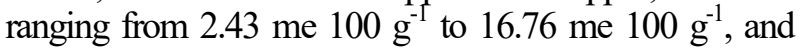
alkaline saturation generally ranges from $5.28 \%$ to $31.1 \%$ with low to very low criteria.

Judging from the breadth, Ultisol has the potential to be developed as agricultural land and can be used for various types of crops but with the condition of medium to high CEC, with a deep crosssection of land, and pay attention to climate factors and reliefs (Sujana \& Pura, 2015). The provision of amelioration materials can overcome the problems in the soil ultisol for the growth and development of plants. Amelioration is an organic material that can improve soil fertility through improved physical and chemical conditions of the soil. Amelioration materials that are often used are compost or bokashi fertilizer, manure, and ash (Suratman \& Sukarman, 2016).

Amelioration chicken manure fertilizer can improve the physical, chemical, and biological properties of soil. Chicken manure fertilizer has a high content of macro and micronutrients that can provide the availability of elements N, P, and K (Akbar, 2016). Chicken manure has a high content of microorganisms that can help the decomposition process and also has very low water content (Aryanti et al., 2017). Based on research Tamura et al. (2017) the administration of chicken manure fertilizer with a dose of 15 tons/ha produced the highest number of soybean pods that is 11.44 pieces per plant.

According to Yunindanova et al. (2014) OPB compost has a high nutrient content, especially $\mathrm{N}$ content of $1.34 \%, \mathrm{P}$ content of $0.08 \%, \mathrm{Mg}$ content of $0.25 \%$, and $\mathrm{K}$ content of $1.38 \%$ because the original ingredient has a high potassium content. Dosing 20 tons $\mathrm{ha}^{-1} \mathrm{OPB}$ produced the largest number of soybean-heated pods with the highest yield production of $1717.2 \mathrm{~g} \mathrm{plot}^{-1}\left(1.2 \mathrm{~m}^{2}\right)$ (Sahputra et al., 2016).

Cow manure has a nutrient content of $\mathrm{C}$ organic $5.9 \%$, N- total $0.9 \%, \mathrm{P}_{2} \mathrm{O}_{5}$-total $0.4 \%$, and $\mathrm{K}_{2} \mathrm{O} 0.3 \%$ (Hanum, 2014). Ramadhani et al. research (2019) shows that chicken manure and cow dung produce the highest plant height performance okra $(29.8 \mathrm{~cm}-31.6 \mathrm{~cm})$, the largest stem diameter $(72.8 \mathrm{~mm}-73.8 \mathrm{~mm})$, the the highest number of branches ( 3 stems), the number of most fruits/plants $(5-7)$, and the largest fruit/plant weight (72.4 g - 81.4.g). Research Tamba et al. (2017) showed that the administration of cow manure fertilizer with a dose of 12 tons $\mathrm{ha}^{-1}$ produced the highest number of pods containing an average of 36.38 pieces per plant and the highest number of productive branches. According to Ekawati \& Purwanto (2012), rice burn husks have content of $\mathrm{K}$ by $0.02 \%$, Ca by $0.45 \%$, and $\mathrm{Mg}$ by $0.05 \%$. The results of Kusuma et al. (2013) showed that the giving of rice burnt husks produced the longest root length of $36.33 \mathrm{~cm}$ and the heaviest root dry weight of $0.20 \mathrm{~g}$.

This study aims to obtain soybean varieties that produce the best growth and yield component in Ultisol on each type of amelioration.

\section{MATERIALS AND METHODS}

This research was conducted from February to May 2019 at the experimental garden of Integrated Agricultural Zone faculty of Agriculture UNIB Medan Baru, Bengkulu City.

This study was compiled using a complete randomized design (CRD) factorial with 2 factors and 3 replays. The first factor is the variety type Anjasmoro and Gepak Kuning, the second factor of amelioration type is control (without amelioration), chicken manure 15 tons ha ${ }^{-1}$,cowmanure 15 tons ha ${ }^{-1}$, husks burn 15 tons $\mathrm{ha}^{-1}$, and compost empty bunches of palm oil (OPB) 15 tons ha ${ }^{-1}$. From both treatments used obtained 10 combinations of treatments, each treatment is repeated 3 times, and for each treatment, there are 3 polybags so that 90 polybags are obtained.

Amelioration mixed into the planting media 2 weeks before planting, by inserting into a polybag and mixed evenly. Each type of amelioration is inserted according to the label that has been given in the polybag. Amelioration is given in the form of chicken manure, cow manure, rice husks, and compost OPB with the same dose of 15 tons ha ${ }^{-1}\left(135 \mathrm{~g} \mathrm{polybag}^{-1}\right)$. Fertilization is done by making a groove with a distance of 7 to 10 $\mathrm{cm}$ from the planting hole. Fertilizer used in the form of urea $\left(0.22 \mathrm{~g} \mathrm{polybag}^{-1}\right)$, TSP $\left(0.90 \mathrm{~g} \mathrm{polybag}^{-1}\right)$, $\mathrm{KCl}\left(0.45 \mathrm{~g} \mathrm{polybag}^{-1}\right)$ (Balai Penelitian Tanah, 2010).

The data obtained is analyzed statistically using variant analysis (ANOVA) at a rate of 5\%. To compare the average between treatments performed with DMRT.

\section{RESULTS AND DISCUSSION}

This research took place from February to May 2019, located at the Experimental Garden of the Faculty of Agriculture, University of Bengkulu, Kandang Limun Village, Muara Bangkahulu District, Bengkulu City. Soil characteristics used during the study showed that the soil has a pH of 4.55 (sour), low N-total content of $0.10 \%$, low $\mathrm{P} 2 \mathrm{O} 5$ content of $7 \mathrm{ppm}, \mathrm{K}$ content available at $25 \mathrm{ppm}$, and low $\mathrm{C}$ Organic content of $1.48 \%$. When viewed from the data, the soil used in this study is classified as in the criteria of less fertile soil (BPPP, 2005). During the study, rainfall ranged from $92 \mathrm{~mm}$ to $460 \mathrm{~mm}$ with a total rainfall 
of $1174 \mathrm{~mm}$ and the average temperature from February to May was $27.2{ }^{\circ} \mathrm{C} ; 27.1{ }^{\circ} \mathrm{C} ; 27.4{ }^{\circ} \mathrm{C}$; and $27.8^{\circ} \mathrm{C}$. This rainfall is sufficient for water needs during soybean growth by the statement Sumarno \& Manshuri (2007) rainfall needed 100 to $150 \mathrm{~mm} / \mathrm{month}$ and the temperature range is optimum for soybean plants that are between 22 to $27^{\circ} \mathrm{C}$.

Soybean seeds begin to germinate 11 days after planting (DAP), in the vegetative period of pest disturbance in the form of ladybugs, caterpillars, and green grasshoppers (Atractomorpha crenulata). Control of attacks of plant destruction organisms in the form of locusts, caterpillars, and ladybugs are controlled preventively by manual means by hand. Harvesting is done when soybeans reach 14 weeks after planting (WAP) which is characterized by yellowing and deciduous leaves, stems have a brownish color, pods on the plant have been dry brown, pod skin has started to open, and seeds have been hard when pressed. The harvest time of soybean crops can not be simultaneous because the cooking age of pods is different. Harvesting is done since soybean plants aged 90 DAP to 101 DAP.

The results of the variant analysis showed that there was a noticeable interaction $(\mathrm{P} \leq 0.05)$ between varieties and amelioration types at height plants. There are real differences between varieties in the observed variables, namely the height of the plant, the number of branches, the number of fertile books, the number of pods per plant, the number of seeds per pod, the weight of 100 seeds, the age of flowering, and the age of harvest.

The types of amelioration differ markedly on the high variables of the plant, the number of branches, the

\begin{tabular}{|c|c|c|c|}
\hline \multirow{2}{*}{ Variable } & \multicolumn{3}{|c|}{ F calculation } \\
\hline & Varieties & Amelioration & Interaction \\
\hline Plant height & $13.37 *$ & $4.35 *$ & $4.04^{*}$ \\
\hline Number of branches & $28.37 *$ & $3.91 *$ & $1.48 \mathrm{~ns}$ \\
\hline Number of fertile books & $31.50 *$ & $6.88 *$ & $1.35 \mathrm{~ns}$ \\
\hline Age of flowering & $12.00 *$ & $0.27 \mathrm{~ns}$ & $0.73 \mathrm{~ns}$ \\
\hline $\begin{array}{l}\text { Number of pods per } \\
\text { plant }\end{array}$ & $17.16^{*}$ & $6.16^{*}$ & $1.29 \mathrm{~ns}$ \\
\hline Age of harvest & $61.79 *$ & $0.95 \mathrm{~ns}$ & $2.85 \mathrm{~ns}$ \\
\hline Number of seeds per pod & $29.44 *$ & $3.67 *$ & $1.13 \mathrm{~ns}$ \\
\hline Weight of seeds per plant & $0.42 \mathrm{~ns}$ & $3.62 *$ & $0.73 \mathrm{~ns}$ \\
\hline Weight of 100 seeds & $61.66^{*}$ & $2.29 \mathrm{~ns}$ & $0.37 \mathrm{~ns}$ \\
\hline Weight of the roots & $0.25 \mathrm{~ns}$ & $3.88 *$ & $1.20 \mathrm{~ns}$ \\
\hline Crown dry weight & $1.08 \mathrm{~ns}$ & $9.58 *$ & $0.55 \mathrm{~ns}$ \\
\hline
\end{tabular}

* significant at $5 \%$ level $(P \leq 0,050)$; ns non significant $(P>0,050)$

number of fertile books, the number of pods per plant, the number of seeds per pod, the weight of seeds per plant, the weight of the roots, and the weight of the dry frame. The following is presented a summary of $F$ calculation on all observation variables (Table 1).
Table 1.Value F calculate varieties, amelioration, and interaction of both to the growth and yield components of soybean crops.

There is a noticeable interaction between soybean varieties and amelioration types at plant height. The Gepak Kuning variety has a higher growth in chicken manure ameliorate followed by OPB when compared to control, cow manure, and rice-burning husks. Anjasmoro varieties have the same plant height in all types of amelioration. Chicken manure and cow manure produce higher plant height among the varieties used. When

\begin{tabular}{l|c|c|c|c|c}
\hline & \multicolumn{5}{|c}{ Amelioration } \\
\cline { 2 - 6 } Varieties & Control & $\begin{array}{c}\text { Chicken } \\
\text { manure }\end{array}$ & $\begin{array}{c}\text { Cow } \\
\text { manure }\end{array}$ & Rice husks & POB \\
\hline Anjasmoro & $57.06 \mathrm{a}$ & $55.00 \mathrm{~b}$ & $53.93 \mathrm{~b}$ & $53.61 \mathrm{a}$ & $61.93 \mathrm{a}$ \\
\hline Gepak & $\mathrm{A}$ & $\mathrm{A}$ & $\mathrm{A}$ & $\mathrm{A}$ & $\mathrm{A}$ \\
\hline Kuning & $51.00 \mathrm{a}$ & $72.46 \mathrm{a}$ & $63.06 \mathrm{a}$ & $62.16 \mathrm{a}$ & $67.40 \mathrm{a}$ \\
\hline Numbers followed by the same lowercase letter in the same column and letter the same \\
\hline \begin{tabular}{l} 
capital on the same line is not significantly different at the 5\% DMRT level \\
\hline
\end{tabular}
\end{tabular}

compared between amelioration species and two varieties, control treatment, rice husks, and OPB have the same plant height but differ in chicken and cow manure. The following are presented the average height of plants on two varieties of soybeans (Table 2).

Table 2. Average plant height for each type of amelioration

Number of fertile books, greater number of pods per plant, higher plant height, and longer harvest life when compared to Anjasmoro varieties. While the number of seeds per pod and the weight of 100 seeds, Anjasmoro is higher than the Gepak Kuning (Table 3),

Plant height is one of the plant sizes that is often

\begin{tabular}{|c|c|c|c|c|c|c|c|c|}
\hline Varities & $\begin{array}{l}\text { Age of } \\
\text { flowering }\end{array}$ & $\begin{array}{l}\text { Number } \\
\text { of } \\
\text { branches }\end{array}$ & $\begin{array}{l}\text { Number } \\
\text { of fertile } \\
\text { books }\end{array}$ & $\begin{array}{l}\text { Number } \\
\text { of pods } \\
\text { per plant }\end{array}$ & $\begin{array}{l}\text { Age of } \\
\text { harvesting }\end{array}$ & $\begin{array}{l}\text { Number } \\
\text { of seeds } \\
\text { per pod }\end{array}$ & $\begin{array}{l}\text { Weight of } \\
100 \\
\text { seeds }\end{array}$ & $\begin{array}{l}\text { Weight } \\
\text { of seeds } \\
\text { per } \\
\text { plant }\end{array}$ \\
\hline Anjasmoro & $37.73 \mathrm{~b}$ & $4.39 \mathrm{~b}$ & $24.29 \mathrm{~b}$ & $56.33 \mathrm{~b}$ & $91.46 \mathrm{~b}$ & $2.72 \mathrm{a}$ & $14.08 \mathrm{a}$ & 16.94 \\
\hline Gepak & & & & & & & & \\
\hline Kuning & $40.20 \mathrm{a}$ & $6.20 \mathrm{a}$ & $39.38 \mathrm{a}$ & $83.69 \mathrm{a}$ & $96.73 \mathrm{a}$ & $2.32 \mathrm{~b}$ & $9.49 \mathrm{~b}$ & 15.07 \\
\hline
\end{tabular}

observed as an indicator of growth as well as a variable to measure the influence of treatment given because the height of the plant is the easiest size to see (Sitompul \& Guritno, 1995). Growth is the process of volume increase that is irreversible due to the process of cell division.

Table 3. Growth rates and yield components of two soybean varieties

Growth can be measured and expressed quantitatively or can be calculated by numbers. In general, the process of high increase of plants is in the vegetative phase that is in the third and fourth week because plants have a high response in absorbing 
nutrients (Purwanto, 2011). The Gepak Kuning variety is higher compared to Anjasmoro. This is by the results of research Dwiputra et al. (2015) which shows that the Gepak Kuning variety has a higher plant height than other varieties such as Argomulyo, Ijen, and Anjasmoro.

The results of this study also showed that the Gepak Kuning variety produced the most branches of 6.20 branches compared to Anjasmoro which is 4.39 branches. Indriani et al. (2014) state that the Gepak Kuning variety produces the largest number of branches of 4.3 branches. Muzaiyanah \& Santoso (2016) stated that the more branches of soybean plants followed by the number of fill pods, the higher the yield obtained. Pieter \& Mejaya (2018) explained that the number of branches and height of plants are more influenced by the genetic properties of plants. Januar et al. (2018) state that on each increase in the number of fertile books and fill pods will increase the weight of seeds per plant. Muzaiyanah \& Santoso (2016) argues that if the soybean plant is too high and has fewer branches will have a small number of fertile books. But if the number of fertile books increases, it has the potential to increase the number of filled pods. This is because the fertile book is where the fill pods are formed.

The number of pods per plant is influenced by the number of branches of the plant. The more branches of the plant, the more pods are formed (Table 3). This is in line with the research of Riyaningsih et al. (2018) which shows that the more productive branches produced, the more pods per plant. Somantri et al. (2018) state that the number of filled pods per plant has an important role in determining the yield of soybean seeds. The role of the number of pods is determined by the contained pods and hollow pods. The more pods fill and the fewer the number of empty pods, the higher the seed yield. The administration of chicken manure as organic fertilizer plays an effective role in adding $\mathrm{N}$ content to the soil (Zainal et al., 2014). The vegetative growth of soybean plants is getting better so that the process of photosynthesis will run well so that the resulting photosynthesis is more and more. Photosynthesis from the vegetative phase to the generative phase will be stored as food reserves in the form of carbohydrates in the form of seeds. The higher the photosintat, the higher the number and yield of seeds.

The weight of 100 seeds of an Anjasmoro variety is higher than the Gepak Kuning (Table 3). This is because Anjasmoro has a larger seed size when compared to Gepak Kuning. Sumadi et al. research (2017) showed that Anjasmoro varieties produced 100 higher seed weights followed by Arjasari and Argomulyo varieties compared to Grobogan varieties. In this study, the Anjasmoro variety produced a weight of 100 seeds heavier than the Gepak Kuning. Anjasmoro has a large seed size, so the weight of 100 seeds obtained is also large. The weight of 100 seeds can be used to indicate the size of the seeds, the larger the weight of 100 seeds, then that means the larger the size of the seeds (Wulandari, 2017).

The flowering age in Anjasmoro varieties is faster on average 38 DAP compared to Gepak Kuning variety which is 40.2 DAP. The difference in flowering age in soybean plants can occur because each variety of soybean has a flowering age that varies according to its genetics and is influenced by the conditions of the outer environment of the plant such as climate differences (length of day and temperature) (Irfhan, 2018). The main factor in flowering in soybean crops is more dominantly influenced by the genetic properties of plants (Justika et al., 1985). Soybean plants include short day crops where soybeans will not flower if the length of the day exceeds the critical limit because each cultivar has a different critical limit. The harvest age of Anjasmoro varieties is on average faster which is 91 DAP compared to the Gepak Kuning variety of 96.73 DAP. The harvest age of soybean crops is very closely related to the age of flowering, so it can be known how long a variety of soybeans do seed replenishment and determination at harvest (Pandiangan, 2012).

In this study the flowering age and harvest age did not match the description, Anjasmoro varieties flowered and harvested faster than Gepak Kuning, while in the opposite description. This is thought to be due to the condition of the plant on the description with different research conducted. Plants on the description maybe planted in soil conditions, climate, and optimal temperature, while in research conducted on soil that is minimal in nutrients, applied with various types of amelioration, and planted in polybags. The possibility of plants experiencing stress, so the age of flowering and harvesting does not fit the description.

Nilahayati \& Putri (2015) states that the age of flowering does not match the description due to the influence of the outside environment of plants that is at the beginning of vegetative growth infected by mosaic viruses so that plants become stressed and flowering age becomes faster. Slow flowering soybeans are likely to produce higher plants, a large number of branches, and a large number of fertile books, as a result of their longer vegetative growth (Rozison, 2012). Proven in this study varieties of Gepak Kuning flowered more slowly than in Anjasmoro, and produced higher plant height, number of branches, and more fertile book count than in Anjasmoro.

The type of chicken manure amelioration gives the highest average value on the number of branches which is 6.21 different branches are not real compared to those produced by the administration of cow manure. Chicken manure has nutrients $\mathrm{N}, \mathrm{P}$, and $\mathrm{K}$. N function is to stimulate overall growth, especially stems, branches, and leaves. Nitrogen also plays an important role in the formation of green leaves that are very useful in the process of photosynthesis (Zainal et al., 2014). Aryanti et al. research (2017) that the $\mathrm{N}$ content in chicken manure belongs to the high category of $0.99 \%$ compared to cow manure $0.9 \%$.

Amelioration chicken manure is the best type of amelioration compared to other types of amelioration. It is 
characterized by a variable number of fertile books, several pods per plant, root weight and dry trapped weight have the highest value. Amelioration chicken manure gives the highest average value on the number of fertile books which is 43.5 segments (Table 4). The number of fertile books is closely related to the number of branches, if the number of branches is small then the number of fertile books produced will be small.

Element $\mathrm{N}$ contained in chicken manure ameliorant has a function to stimulate the overall growth of one of them in the branch (Zainal et al., 2014). In this study, a large number of branches resulted in a large number of fertile books. Chicken manure can improve soil

\begin{tabular}{l|l|l|l|l|l|l|}
\hline Amelioration & $\begin{array}{c}\text { Number } \\
\text { of fertile } \\
\text { books }\end{array}$ & $\begin{array}{c}\text { Number } \\
\text { of pods } \\
\text { per plant }\end{array}$ & $\begin{array}{c}\text { Number of } \\
\text { seed per } \\
\text { plant }\end{array}$ & $\begin{array}{c}\text { Weight of } \\
\text { seeds per } \\
\text { plant }\end{array}$ & $\begin{array}{c}\text { Weight of Corwn dry } \\
\text { the roots } \\
\text { weight }\end{array}$ \\
\hline Control & $22.61 \mathrm{c}$ & $52.1 \mathrm{~b}$ & $2.25 \mathrm{~b}$ & $9.81 \mathrm{~b}$ & $5.88 \mathrm{~b}$ & $11.76 \mathrm{c}$ \\
\hline Chicken manure & $43.5 \mathrm{a}$ & $98.33 \mathrm{a}$ & $2.64 \mathrm{a}$ & $24.5 \mathrm{a}$ & $14.63 \mathrm{a}$ & $27.88 \mathrm{a}$ \\
\hline Cow manure & $33.13 \mathrm{~b}$ & $72.96 \mathrm{~b}$ & $2.53 \mathrm{a}$ & $19.58 \mathrm{ab}$ & $9.07 \mathrm{~b}$ & $18.46 \mathrm{~b}$ \\
\hline Rice husks & $26.9 \mathrm{bc}$ & $55.5 \mathrm{~b}$ & $2.55 \mathrm{a}$ & $11.03 \mathrm{~b}$ & $7.34 \mathrm{~b}$ & $14.61 \mathrm{bc}$ \\
\hline POB & $33.03 \mathrm{~b}$ & $71.16 \mathrm{~b}$ & $2.64 \mathrm{a}$ & $15.1 \mathrm{ab}$ & $8.56 \mathrm{~b}$ & $19.91 \mathrm{~b}$ \\
\hline $\begin{array}{l}\text { The numbers followed by the same letter in the same column are not significantly different at the } \\
\text { 5\% DMRT level }\end{array}$
\end{tabular}

structure and soil aeration to cause the development of roots to be longer so that the roots are easier to absorb nutrients and plant growth is getting better and obtain high yields (Duaja, 2012).

Table 4. Average growth and yield components of soybean for each types of amelioration

The amelioration type of chicken manure gives the highest average value on the number of pods per plant is 98.33 pods. Tamura et al., (2017) stated that the addition of chicken manure can provide nutrients for plants, especially chicken manure contains higher P nutrients compared to other manure. Nutrients $P$ utilized plants in the generative phase that is in soybean plants are utilized in the process of forming and ripening pods. Tamura et al. research (2017) chicken manure treatment of 15 tons ha ${ }^{-1}$ gives the largest number of pods per plant which is 11.44 pods. Sutejo (2002) stated that the element $\mathrm{P}$ plays a role in increasing the seed replenishment of soybean crops so that giving high $\mathrm{P}$ will increase the weight of soybean plant seeds. The more element $P$ is available to plants, the more that can be absorbed by plants, so photosynthesis will increase and will eventually increase the weight of seeds per plant.

In the number of seeds per pod of chicken manure gives the highest average value of 2.64 different seeds are not real with the type of cow manure amelioran, grilled husks and OPB. The increase in the number of seeds per pod depends on the dose of compost of livestock manure administered into the soil. If the compost given is increasing, the number of seeds per green bean pod will also increase (Nenobesi, 2017). The increase in the number of seeds per pod is thought to be because the compost provided can increase the availability of nutrients needed by plants, especially phosphorus, $\mathrm{Ca}$ and $\mathrm{Mg}$ elements needed for the formation of flowers, fruits and seeds.

Chicken manure gives the highest average value on seed weight per plant which is $24.5 \mathrm{~g}$, in contrast to cow manure and OPB. Proven in this study, chicken manure gives the highest average value on the number of fertile books and the number of pods per plant so that the weight of seeds per plant produced is also a lot. This is thought to be due to the growth and development of vegetative organs of plants well because the growth elements needed enough, so generative development is also good, proven from this study, resulting in the number of branches, the number of fertile books, the number of pods per plant, and the number of seeds per pod a lot. Zainal et al. (2014) stated that the increase in seed weight per plant is related to the increase in the number of soybean plant leaves because, with the increase in the number of leaves, the more light can be captured, thus the opportunity to increase the process of photosynthesis and the potential of assimilating translocated to seeds, so that the resulting seeds will also increase.

Chicken manure gives the highest average value at the root weight of $14.63 \mathrm{~g}$. This is thought to be because chicken manure contains high nutrients that can improve the physical, chemical, and biological properties of the soil. Proven from soil analysis in this study that chicken manure can increase the $\mathrm{pH}$ to 5.01 with a water content of $34.28 \%$ compared to cow manure 4.58 with a water content of $14.77 \%, 4.65$ rice burn husks with a water content of $17.34 \%$, OPB 4.70 with a water content of $12.86 \%$, and without amelioration administration of 4.55 with a water content of $20.23 \%$. The higher the moisture content, the better for plants because the more water available. The administration of chicken manure is most able to hold water in the soil meaning that when evaporation occurs, plants are still able to hold water in the soil. Plants treated with chicken manure were able to improve the yield of soybeans in this study through two processes, namely through a high $\mathrm{pH}$, to provide better nutrients and the ability of the soil to hold water. The high ability of soil given chicken manure to hold water is likely caused by a high organic $\mathrm{C}$ content.

Duaja (2012) explained that giving $50 \mathrm{~g}$ of solid chicken manure fertilizer can produce more organic $\mathrm{C}$, thus creating a better physical environment. It is seen from the content of soil organic $\mathrm{C}$ treated solid organic fertilizer contains organic $\mathrm{C}$ higher than $\mathrm{C}$ organic soil gave urea treatment, liquid chicken manure, and without fertilizer. The situation is thought to create a better soil structure, the availability of $\mathrm{N}$ for plants is quite large so that the development of roots becomes better and the ability of plants $\mathrm{N}$ absorbs from the ground becoming larger. This can be seen from plants that are treated with solid organic fertilizer resulting in fresh weight and the root weight of lettuce plants are much greater than other treatments. Chicken manure gives the highest average value at a dry weight of 
27.88 g. Utomo et al. (2017) state that the dry weight of plants is an accumulation of organic matter produced by plants through the process of photosynthesis. Chicken manure provides higher nutrients to improve the physiological processes of plants such as photosynthesis processes which are then used to form plant organs such as branches and leaves, to increase the yield of the dry weight of plants.

\section{CONCLUSION}

The Gepak Kuning variety showed better growth than the Anjasmoro variety with the number of branches (6.20 branches), the number of fertile books (39.38 segments), and the height of the plant $(63.22 \mathrm{~cm})$, while the Anjasmoro variety showed better results than the Gepak Kuning variety with more seeds per pod (2.72 seeds) and a weight of 100 seeds heavier (14.08 g).

Chicken manure is the best types of amelioration compared to cow manure, rice husks, and palm empty bunch compost against the growth and component of soybean yield in Ultisol with the number of branches (6.21 branches), the number of fertile books ( 43.5 segments), the number of pods per plant ( 98.33 pods), root weight (14.63 g), and dry weight (27.88 g).

There is an interaction between the amelioration species of chicken manure and cow manure in both varieties, where the difference is seen when there is a combination of chicken manure and cow manure with the varieties Anjasmoro and Gepak Kuning shows a higher plant height compared to other types of amelioration.

\section{References}

Akbar, Y. (2016). Respon pertumbuhan dan hasil tanaman bawang daun (Allium fistulosum L.) akibat pemberian beberapa jenis pupuk kandang. Jurnal Menara Ilmu, 10(72), 141-147.

Aryanti, E., Yulita \& Annisava, A.R. (2017). Pemberian beberapa amelioran terhadap perubahan sifat kimia tanah gambut. Jurnal Agroteknologi. 7(1), 19-26.

Badan Pusat Statistik. (2017). Import kedelai. https:// www.bps.go.id/all_newtemplate.php. 21_November 2018.

Balai Penelitian Tanah. (2010). Rekomendasi pemupukan tanaman kedelai pada berbagai tipe penggunaan lahan. http://balittan.litbang.deptan. go.id. 12 Oktober 2018.

Duaja. W. (2012). Pengaruh pupuk urea, pupuk organik padat dan cair kotoran ayam terhadap sifat tanah, pertumbuhan dan hasil selada keriting di Tanah Inceptisol. Jurnal Fakultas Pertanian. 1(4), 236246.

Dwiputra, A.H., Indradewa, D. \& Susila, E.T. (2015). Hubungan komponen hasil tiga belas kultivar kedelai (Glycine max L. Merrill). Jurnal Vegetalika. 4(3), 14-28.
Ekawati, I. \& Purwanto, Z. (2012). Potensi Abu Limbah Pertanian Sebagai Sumber Alternatif Unsur Hara Kalium, Kalsium, dan Magnesium untuk Menunjang kelestarianProduksi Tanaman. Fakultas Pertanian Univeritas Wiraraja, Sumenep.

Fitriatin, B.N., Yuniarta, A., Turmuktini, T. \& Ruswandi, F.K. (2014). The effect of phosphate solubilizing microbe producing growth regulators on soil phosphate, growthand yield of maize and fertilizer efficiency on Ultisol. Eurasian Journal Of Soil Science (EJSS), 3(2), 101-107.

Indriani, F. C., Kuswantoro, H. \& Supeno, A. (2014). Perubahan Karakteristik Agronomi Beberapa Varietas Kedelai yang di Radiasi Sinar Gamma. Balai Penelitian TanamanAneka Kacang dan Umbi. Prosiding Seminar Hasil Penelitian Tanaman Aneka Kacang dan Umbi.

Januar, F. H., Karyawati, A.S. \& Sitompul, S.M. (2018). Potensi Genetik Generasi F3 Hasil Persilangan Tanaman Kedelai (Glycine max L. Merrill) Varietas Argopuro Sebagai Tetua Betina dengan Varietas Tanggamus, Grobogan dan Galur UB Sebagai tetua jantan. Jurnal Produksi Tanaman, 6(3), 392397.

Justika, S., Baharsjah, D. Suardi dan I. Las. 1985. Hubungan Iklim dengan Pertumbuhan Kedelai, hal 87. In S. Somaatmadja, M.Ismunadji, Sumarno, M. Syam. S. O. Manurung, dan Yuswadi (Eds) Kedelai, Badan Penelitian dan Pengembangan Pertanian. Pusat Penelitian dan PengembanganTanaman Pangan. Bogor.

Kementerian Pertanian RI. 2018). Produksi Kedelai Menurut Provinsi. https://www.pertanian.go.id/ Data5tahun/TPATAP-2017(pdf)/24-Prod Kedelai.pdf. 14 November 2019.

Kusuma, A.H., Izzati, M. \& Saptiningsih, E. (2013). Pengaruh penamabahan akar dan abu sekam dengan proporsi yang berbeda terhadap permeabilitas dan porositas tanah liat serta pertumbuhan kacang hijau (Vigna radiate L). Buletin Anatomo dan Fisiologi, 21(1), 1-9.

Muzaiyanah, S. \& Santoso, G.W.A. (2016). Hubungan Beberapa Karakter Agronomi Terhadap Hasil Kedelai Toleran Kekeringan. Prosiding Seminar Hasil Penelitian Tanaman Aneka Kacang dan Umbi, Malang.

Nenobesi, D., W. Mella dan P. Soetedjo. 2017. Pemanfaatan Limbah Padat Kompos Kotoran Ternak dalam Meningkatkan Daya Dukung Lingkungan dan Biomassa Tanaman Kacang Hijau (Vigna Radiate L.). Varietas Vima 1. Jurnal Bumi Lestari. 17(1): 69- 81.

Nilahayati dan L.A.P.Putri. 2015. Evaluasi Keragaman Karakter Fenotipe Beberapa Varietas Kedelai (Glycine max L. Merrill) di Daerah Aceh Utara. J. Floratek. 10(1): 36-45. 
Pandiangan, M. (2012). Uji Daya Hasil Kedelai (Glycine max L. Merrill) Berdaya Hasil Tinggidi Kampung Sidey Makmur SP 11 Manokwari. Skripsi Program Studi Agronomi Fakultas Pertanian dan Teknologi Pertanian Universitas Negeri Papua Manokwari.

Pieter, Y. \& Mejaya, M.J. (2018). Pengaruh pemupukan hayati terhadap pertumbuhan dan hasil kedelai di lahan sawah. Penelitian Pertanian Tanaman Pangan. 2(1): 51-57.

Prasetyo, B.H. \& Suriadikarta, D.A. (2006). Karakteristik, potensi, dan teknologi pengelolaan tanah ultisol untuk pengembangan pertanian lahan kering di Indonesia. Jurnal Litbang Pertanian. 25(2), 3946.

Purwanto. (2011). Budidaya Tanaman Tomat. Agromedia, Jakarta.

Ramadhani, C., Sumardi \& Gonggo, B.M. (2019). Pemberian dua jenis amelioran terhadap performa tanaman Okra (Abelmoschus esculentus) pada Ultisol. Jurnal Ilmu-Ilmu Pertanian Indonesia, 21(2), 121-128.

Riyaningsih, A.D., Supriyono \& Jauhari, S. (2018). Pertumbuhan dan hasil kacang hijau dari berbagai populasi dengan mulsa organik. Agrotechnology Research Journal, 2(2), 58-62.

Rozison. (2012). Karakterisasi Galur-Galur Harapan Kedelai (Glycine max L. Merrill) yang Efisien Menggunakan Fosfor (P). Skripsi, Fakultas Pertanian. Universitas Bengkulu, Bengkulu. (Tidak dipublikasikan).

Sahputra, N., Yulia, A.E. \& Silvina, F. (2016). Pemberian kompos tandan kosong kelapa sawit dan jarak tanam pada kedelai Edamame (Glycine max L. Merrill). Jurnal Online Mahasiswa (JOM) Bidang Pertanian, 3(1), 1-12.

Sitompul, S. M \& Guritno, B. (1995). Analisis Pertumbuhan Tanaman. Gadjah Mada. University Press., Yogyakarta.

Somantri, R. U., Syahri \& Thamrin, T. (2018). Potensi Hasil Beberapa Varietas Unggul Baru (VUB) Kedelai di Lahan Kering Sumatera Selatan. Prosiding Seminar Nasional Lahan Suboptimal. Palembang, 18-19 Oktober 2018.

Sudaryanto, T. \& Swastika, D.K.S. (2007). Ekonomi Kedelai di Indonesia. In Sumarno, Suyamto, A. Widjono, Hermanto, dan H. Kasim (Eds) Kedelai, Teknik Produksi dan Pengembangan. Badan Penelitian dan Pengembanagan Pertanian. Pusat Penelitian dan Pengembangan Tanaman Pangan, Bogor.

Sujana, I.P. \& Pura,I.N.I.S.. (2015). Pengelolaan tanah ultisol dengan pemberian pembenah organik biochar menuju pertanian berkelanjutan. Jurnal Agrimeta, 5(9), 01-69.
Sumadi., Kadapi, M., Nuraeni, A., Wicaksana, N., Rachmadi, M. \& Rodiah, S. (2017). Hasil benih empat kultivar kedelai yang ditanam di dataran medium dan dataran tinggi. Jurnal Kultivasi, 16 (3), 502-506.

Sumarno dan A. G. Manshuri. (2007). Persyaratan Tumbuh dan Wilayah Produksi Kedelai DiIndonesia. Pusat Penelitian dan Pengembangan Tanaman Pangan Bogor, Balai Penelitian Tanaman Kacang -kacangan dana Umbi-umbian, Malang. Pp. 74103.

Suratman \& Sukarman. (2016). Peran amelioran tanah mineral terhadap peningkatan berbagai unsur kesuburan tanah gambut pada perkebunan kelapa sawit. Jurnal Sumberdaya Lahan Edisi Khusus, 21-32.

Suryati, D., Munawar, A., Ganefianti, D.W., Hasanudin \& Apriyanto, D. (2000). Perakitan varietas kedelai (Glycine max L. Merrill) yang Efisien Menyerap Hara P,Pewarisan Sifat Efisiensi P. Laporan Penelitian Hibah Bersaing V/5 Perguruan Tinggi. Lembaga Penelitian Universitas Bengkulu, Bengkulu.

Susilawati, H.I., Ariani, M., Kartikawati, R. \& Setyanto, P. (2011). Ameliorasi Tanah Gambut Meningkatkan Produksi Padi dan Menekan Emisi Gas Rumah Kaca. BadanLitbang Pertanian, Jakarta.

Sutejo, M. M. (2002). Pupuk dan Cara Pemupukannya. PT Rineka Cipta, Jakarta.

Syahputra, E., Fauzi \& Razali. (2015). Karakteristik sifat kimia sub grup tanah ultisol di beberapa wilayah Sumatera Utara. Jurnal Agroekoteknologi Universitas Sumatera Utara, 4(1), 1796-1803.

Tamba, H., Irmansyah T. \& Hasanah, Y. (2017). Respon pertumbuhan dan produksi kedelai (Glycine max L. Merrill) terhadap aplikasi pupuk kandang sapi dan pupuk organik cair. Jurnal Agroekoteknologi Universitas Sumatera Utara. 5(2), 307-314.

Tamura, P., Soelistyono, R. \& Guritno, B. (2017). Pengaruh jarak tanam dan dosis pemberianpupuk kandang ayam terhadap pertumbuhan dan hasil tanaman kedelai (Glycine max L. Merrill). Jurnal Produksi Tanaman, 5(8), 1329-1337.

Tanuwijaya, L.K., Gita, A.P., Ummi, I.I., Kusuma, T.S. \& Ruhana, A. (2016). Potensi "khimelor" sebagai tepung komposit tinggi energi tinggi protein berbasis pangan lokal (health potential of "khimelor" as composite fluor having both high energy and high protein level based on local food). Indonesian Journal of Human Nutrition, 3 (1), 71- 79.

Utomo, S. A., Purnamasari, R.T. \& Pratiwi, S.H. (2017). Pemanfaatan kompos kotoran ayam untuk pertumbuhan dan hasil tanaman kedelai hitam (Glycine soya Benth). Jurnal Agroteknologi Merdeka Pasuruan, 1(1), 22-27. 
Indriani, Suryati, Pujiwati, Prasetyo, Sukarjo

Wulandari, A. L. (2017). Produktivitas Empat Galu Kedelai (Glycine max L. Merrill) Pada Berbagai Kombinasi Perlakuan Pemupukan. Skripsi, Fakultas Pertanian Institut Pertanian Bogor, Bogor.
Zainal, M., Nugroho, A. \& Suminarti, N.E. (2014). Respon pertumbuhan dan hasil tanamankedelai (Glycine max L. Merrill) pada berbagai tingkat pemupukan $\mathrm{N}$ dan pupuk kandang ayam. Jurnal Produksi Tanaman, 2 (6), 484-490. 